\title{
A systematic review of the use of ketogenic diets in adult patients with cancer
}

DOI:

10.1111/jhn. 12587

\section{Document Version}

Accepted author manuscript

Link to publication record in Manchester Research Explorer

\section{Citation for published version (APA):}

Sremanakova, J., Sowerbutts, A. M., \& Burden, S. (2018). A systematic review of the use of ketogenic diets in adult patients with cancer. Journal of Human Nutrition and Dietetics, [doi: 10.1111/jhn.12587].

https://doi.org/10.1111/jhn.12587

\section{Published in:}

Journal of Human Nutrition and Dietetics

\section{Citing this paper}

Please note that where the full-text provided on Manchester Research Explorer is the Author Accepted Manuscript or Proof version this may differ from the final Published version. If citing, it is advised that you check and use the publisher's definitive version.

\section{General rights}

Copyright and moral rights for the publications made accessible in the Research Explorer are retained by the authors and/or other copyright owners and it is a condition of accessing publications that users recognise and abide by the legal requirements associated with these rights.

\section{Takedown policy}

If you believe that this document breaches copyright please refer to the University of Manchester's Takedown Procedures [http://man.ac.uk/04Y6Bo] or contact uml.scholarlycommunications@manchester.ac.uk providing relevant details, so we can investigate your claim.

\section{OPEN ACCESS}


Journal of

Human Nutrition

and Dietetics

\section{A systematic review of the use of ketogenic diets in adult patients with cancer}

\begin{tabular}{|r|l|}
\hline Journal: & Journal of Human Nutrition and Dietetics \\
\hline Manuscript ID & JHND-18-03-0087-IR.R1 \\
\hline Manuscript Type: & Invited Review \\
\hline Section: & Clinical Nutrition \\
\hline \multicolumn{2}{|l}{} \\
\hline
\end{tabular}

SCHOLARONE ${ }^{m}$

Manuscripts 


\section{Abstract}

2 Background

3 A growing body of evidence indicates the importance of nutrition in cancer treatment.

4 Ketogenic diets are one of the strategies that have been proposed to enhance traditional

5 anti-cancer therapy. This review summarises the evidence on the effect of oral ketogenic

6 diets on anthropometry, metabolism, quality of life (QoL) and tumour effects whilst

7 documenting adverse events and adherence in patients with cancer.

\section{$8 \quad$ Methodology}

9 We searched electronic databases using medical subject headings (MeSH) and text words related to ketogenic diets and cancer. Adult patients following a ketogenic diet as a complementary therapy prior, alongside or after standard anti-cancer treatment for longer than 7-days were included. Studies were assessed for quality using the Critical Appraisal Skills Programme tools.

\section{Results}

Eleven studies were included with 102 participants, (age range 34-87 years) from early phase trials, cohort studies and case reports. Studies included participants with brain, rectal or mixed cancer sites with early or advanced disease stage. The duration of intervention ranged from 2.4-134.7 weeks (0.5-31 months). Evidence was inconclusive for nutritional status and adverse events. Mixed results were observed for blood parameters, tumour effects and QoL. Adherence to diet was low (50 out of 102, 49\%) and ranged from $23.5-100 \%$.

\section{Conclusion}

High-quality evidence on the effect of ketogenic diets on anthropometry, metabolism, QoL and tumour effects is currently lacking in oncology patients. Heterogeneity between studies and low adherence to diet affects the current evidence. There is an obvious gap in the evidence highlighting a need for controlled trials to fully evaluate the intervention.

$\begin{array}{ll}50 \\ 51 \\ 52 & \\ 53 & \\ 54 & \\ 55 & \\ 56 & \\ 57 & \\ 58 & \\ 59 & \\ 60 & \end{array}$




\section{Introduction}

There is a growing recognition of the impact of nutritional interventions on health outcomes ${ }^{(1 ; 2)}$ and supportive health seeking behaviour of people with cancer ${ }^{(3 ; 4)}$. As part of this phenomena, ketogenic diets (KD) have generated interest due to their potential to affect cancer metabolism.

KD are high in fat and low in carbohydrate ${ }^{(5)}$. The exact proportions of macronutrients depend on specific type of diet ${ }^{(6 ; 7 ; 8 ; 9)}$. The most frequently used diet is a $4: 1$ fat to carbohydrate+protein ratio diet ${ }^{(6 ; 10)}$. The diet is based on complex physiological adaptations enabling increased utilisation of fat and ketones ${ }^{(5)}$.

A justification for KD is based on Otto Warburg's observation that most cancer cells follow an altered metabolic pathway, relying on anaerobic glycolysis, even in the presence of oxygen ${ }^{(11)}$. Also, cancer cells strategically use glycolysis for rapid cell proliferation ${ }^{(12)}$ and metastases formation ${ }^{(13)}$. Data from cellular and animal studies support and extend Warburg's conclusions ${ }^{(14 ; 15 ; 16 ; 17)}$. Reviews concentrating on tumour-suppressive mechanisms behind the diet combine available data from cellular, animal and clinical studies $^{(15 ; 18 ; 19 ; 20)}$. Clinical evidence alone was reviewed in four articles. However, these reviews have a number of limitations including unspecified inclusion criteria, combining studies of parenteral and enteral nutrition, short duration on a KD that would not result in any potential benefits that could be attributed to ketosis, and studies that did not report or measure ketones ${ }^{(21 ; 22 ; 23 ; 24)}$. In addition, none of the studies assessed the quality of evidence using risk assessment tools. Currently, rigorously reviewed evidence from a dietetic perspective on oral KD is lacking.

KD have the potential to influence many physiological processes. Patients with cancer may incur weight loss, muscle wasting, and severe inflammation ${ }^{(25)}$ which can lead to morbidity and poorer quality of life $(\mathrm{QoL})^{(26)}$. It is therefore important to determine if $K D$ adversely affect nutritional status in people with cancer.

The aim of this systematic review is to evaluate the current evidence on anthropometry, metabolic changes and systemic inflammation in people with cancer following a KD.

\section{Materials and methods}

This systematic review was registered with the International Prospective Register of Systematic Reviews (PROSPERO) on 15 September 2017 (registration number 
CRD42017074011) and followed the Preferred Reporting Items for Systematic Reviews and Meta-Analyses (PRISMA) guidelines ${ }^{(27)}$.

\section{Data sources, search strategy and selection criteria}

We identified relevant studies using medical subject headings (MeSH) and text words related to KD and cancer. The following databases were searched: MEDLINE, Embase, CINAHL, Cochrane Central Register of Controlled Trials (CENTRAL), Web of Science and PROSPERO. Conference abstracts were included in the search, along with

ClinicalTrials.gov to identify ongoing trials. The main search strategy was created by a specialist librarian and was amended for the other databases (Supplementary Material A). Identified non-English language studies were translated.

Randomised and nonrandomised control trials, prospective cohort studies, retrospective cohort studies, observational and case studies with adults (>18 years) diagnosed with any type of cancer, at any stage of treatment receiving a KD were included. A KD was defined as any dietary manipulation of fat, carbohydrate and protein in order to achieve ketosis ${ }^{(5)}$. Studies that used KD as a complementary therapy prior, alongside or after standard anticancer treatment for longer than 7-days were included. We excluded studies that did not monitor ketosis during the intervention and studies with more than one intervention.

The primary outcome was changes in anthropometrics, namely body weight, the proportion of muscle mass and fat mass. Secondary outcomes were metabolic changes including glucose level, insulin level, insulin growth factor 1 (IGF-1), cholesterol and lipid levels, C- reactive protein (CRP), ketone levels, tumour size, tumour growth markers, QoL, adherence and adverse events.

The results of the literature searches were uploaded to Covidence (Version 1.0, Denmark, 2017). Duplicates were removed. The titles and abstracts were independently screened by two researchers, full text of selected abstracts were obtained and screened to identify the eligible publications; see PRISMA flow diagram ${ }^{(27)}$.

Quality appraisal

Studies were assessed for quality using the Critical Appraisal Skills Programme tools for cohort studies (CASP) ${ }^{(28)}$ (Supplementary Material B).

Data synthesis 
94

95

96

97

98

99

100

101

102

103

104

105

106

107

108

109

110

111

112

113

114

115

116

117

118

119

120

121

122

123

124

No studies were suitable for pooling the results, so a narrative analysis was presented.

\section{Results}

A total of 2367 titles were identified. In addition, 15 studies were found through manual searching. After removal of 130 duplicates, 2252 abstracts were screened, and 2217 studies then excluded. Subsequently, 35 full texts were assessed for eligibility. From those, 24 were excluded (details in Supplementary Material C). Eleven studies were included. See PRISMA diagram (Figure1).

\section{Synthesis}

Study characteristics

We included three early phase single arm clinical trials ${ }^{(29 ; 30 ; 31)}$, three prospective cohort studies $^{(32 ; 33 ; 34)}$, one retrospective review ${ }^{(35)}$ and four case reports ${ }^{(6 ; 36 ; 37 ; 3)}{ }^{\text {. Only two }}$ studies were designed to compare intervention and control groups, one retrospective review ${ }^{(35)}$ and one prospective study ${ }^{(34)}$. A total of 102 participants followed KD and the age ranged between 34 to 87 years. Mean baseline body mass index (BMI) ranged from $23.5 \pm 6$ to $29.46 \pm 5 \mathrm{~kg} \cdot \mathrm{m}^{2}$. Participants in eight studies had advanced cancer stage ${ }^{(31 ; 32 ; 33 ;}$ $34 ; 35 ; 36 ; 38)$. In three studies, cancer stage ranged from an early to more advanced stage ${ }^{(6}$; 29; 37). Five studies involved participants with brain cancer $(31 ; 34 ; 35 ; 36 ; 38)$, one study rectal cancer $^{(6)}$ and five studies had participants with mixed cancer sites ${ }^{(29 ; 30 ; 32 ; 33 ; 37)}$. Duration of intervention ranged from 2.4 to 134.7 weeks. KD were used as a sole therapy or in combination with standard therapies, and this differed not only between studies but within studies (Table 1).

Study quality

Quality of evidence was very low. The cohort studies had limited information on participants' eligibility and details of recruitment were only reported in two studies ${ }^{(30 ; 31)}$. Exposure to KD was only accurately measured in one study ${ }^{(33)}$ which monitored ketosis, energy and nutrient intake. Outcomes were accurately measured in three studies ${ }^{(29 ; 32 ; 33)}$. All studies identified the main confounding factors; however, no study adjusted for them. Follow up was long enough in all studies. Studies lacked precision and reliability, having 
125 small sample size, insufficient statistical analysis, and multiple limitations in the design,

126 methodology and outcomes reported.

127 Intervention

128

129

130

131

132

133

134

135

136

137

138

139

140

141

142

143

144

145

146

147

148

149

150

151

152

153

154

155

All studies investigated the effect of oral KD; however, there was considerable variation in how the diet was delivered. Three studies followed a traditional KD with 4:1 or 3:1 fat to carbohydrate+protein ratio $(\mathrm{F}: \mathrm{CHO}+\mathrm{P})^{(29 ; 34 ; 38)}$, two studies used ratio $\mathrm{F}: \mathrm{CHO}+\mathrm{P}$ between 0.7:1 to $1.8: 1^{(33 ; 37)}$, three studies used Modified Atkins diet $(20-40 \mathrm{~g} / \text { day CHO })^{(30 ; 35 ; 36)}$, two studies used low glycaemic index diet $(<70 \mathrm{~g} / \text { day } \mathrm{CHO})^{(31 ; 32)}$ and one study used Paleolithic KD with $\mathrm{F}: \mathrm{P}$ ratio $2: 1^{(6)}$.

All studies encouraged participants to eat to satiety, however, only two studies reported on energy and macronutrient intake ${ }^{(33 ; 3)}$. Four studies involved a dietitian or nutritionist ${ }^{(29 ;}$ $34 ; 37 ; 38$, and seven studies applied some form of dietary monitoring which included a tailored dietary regimen with provided meals ${ }^{(29)}$, food diaries ${ }^{(37)}$, dietary recall ${ }^{(33)}$, diet software ${ }^{(35)}$, telephone calls ${ }^{(38)}$, or telephone calls and in-person visits ${ }^{(6 ; 32)}$. The adherence was assessed by study completion and measuring the level of ketosis. Urine ketosis was measured with or without blood analysis taken daily, weekly, biweekly or at set time points (Supplementary Material D).

\section{Primary and secondary outcomes}

Anthropometry

Nine studies measured body weight and reported a mean weight loss of $1.86 \mathrm{~kg}$ to $13 \mathrm{~kg}$. Weight was measured between 2.4 weeks to 97.8 weeks (22.5 months). Fine (2012) monitored energy intake, observing a $4 \%$ mean decrease in weight but a mean energy deficit of $35 \%{ }^{(33)}$. Klement (2016) also monitored energy intake and observed significant weight loss albeit in patients on a hypocaloric diet intending to lose weight ${ }^{(37)}$. Champ (2014) reported similar findings ${ }^{(35)}$. Five studies ${ }^{(6 ; 29 ; 30 ; 31 ; 32 ; 36)}$ reported a significant reduction in weight, but did not report on energy intake. One study did not observe a significant weight loss ${ }^{(36)}$. Five studies reported a decrease in $\mathrm{BMI}^{(6 ; 30 ; 32 ; 36 ; 38)}$ consistent with weight loss. Body composition was measured by one study ${ }^{(37)}$; observing a decrease in fat mass and an increase in muscle mass relative to body weight (Table 2). 
156

157

158

159

160

161

162

163

164

165

166

167

168

169

170

171

172

173

174

175

176

177

178

179

180

181

182

183

184

185

186

187

Biochemical parameters

\section{Blood glucose}

Ten studies assessed blood glucose at baseline and follow up. Four studies reported a decrease in blood glucose ${ }^{(6 ; 32 ; 33 ; 35)}$, five reported no significant changes ${ }^{(29 ; 30 ; 31 ; 36 ; 37)}$ and one study showed problems with maintenance of glucose below $80 \mathrm{mg} / \mathrm{dl}^{(38)}$. Two studies reported on correlation between beta hydroxyl butyrate (BHB) and glucose concentration. One study found significant negative correlation $(p=0.05)^{(37)}$, while other reported no significant change ${ }^{(30)}$.

\section{Lipid profile}

Seven studies reported on changes in blood lipids. Four studies did not observe any significant changes in triglycerides (TG), cholesterol, high density lipoprotein (HDL) and low density lipoprotein $(L D L) ~(30 ; 31 ; 36 ; 37)$. One study reported a significant drop in LDL and $\mathrm{HDL}^{(32)}$. One study observed elevated lipid enzymes, with stable TG ${ }^{(6)}$ and two studies reported an elevated cholesterol and $\operatorname{LDL}^{(6 ; 38)}$.

\section{Other parameters}

Studies reported on kidney ${ }^{(6 ; 30 ; 33)}$, liver ${ }^{(6 ; 30 ; 32 ; 37)}$ and thyroid function ${ }^{(6 ; 37)}$ with no changes in measured markers. Also, there were no differences in inflammatory markers in two studies ${ }^{(33 ; 37)}$, while one study reported a decrease in CRP ${ }^{(6)}$. A negative correlation between BHB and insulin but not IGF-1 and IGF-2 were reported in one study ${ }^{(33)}$. The decrease in insulin was observed in participants who achieved a 10 to 35 fold increase $(p=0.018)$ in ketosis ${ }^{(33)}$, however, no changes were reported in another study ${ }^{(37)}$. In participants with diabetes, one reported a $75 \%$ decrease in insulin taken compared to baseline ${ }^{(32)}$ and one stopped insulin doses completely ${ }^{(30)}$. One study reported a significant increase $(p<0.05)$ in the level of the plasma protein carbonyl (biomarker of oxidative stress) compared to baseline ${ }^{(29)}$. For details on all biochemical parameters see Table 2.

Tumour effects

All eleven studies reported on tumour stability and progression, however, the diagnostic tool used was only reported in eight studies; four used magnetic resonance imaging ${ }^{(6 ; 31 ;}$ ${ }^{34 ; 38)}$, three used positron emission tomography ${ }^{(30 ; 33 ; 38)}$, and one used computed tomography scans ${ }^{(30)}$. Due to low compliance, most of the studies could not perform any probability statistical analysis on effect size. One study compared results between 
188

189

190

191

192

193

194

195

196

197

198

199

200

201

202

203

204

205

206

207

208

209

210

211

212

213

214

215

216

217

218

219

participants who were adherent or not adherent to the diet ${ }^{(33)}$. Patients with 3-fold higher ketosis had stable disease or partial remission compared to those with progressive diseases $(p=0.018)^{(33)}$. One study reported $50 \%$ reduction in seizure frequency after 13.2 months follow up ${ }^{(36)}$. Some studies reported outstanding results in some patients, whilst in others the disease progressed (Table 2).

Survival

Zahra (2017) showed no difference in survival between patients who adhered to a diet and those who stopped after 22 months ${ }^{(29)}$. Champ (2014) reported that four patients were alive, three with recurrence after 14 months of follow up, one patient without recurrence for 12 months and two patients died after 6.3 months and 20 months ${ }^{(35)}$. Rieger (2014) showed that patient's survival from the time of the diet was 32 weeks (range 6 to 86 weeks) and compared survival with patients treated with standard therapy, however, results showed no difference. Further, the study showed a trend in longer progression free survival in patients with stable ketosis $(p=0.069)^{(31)}$. In the study by Tan-Shalaby (2016), from the four patients that completed the intervention, survival ranged from 40 to 131 months from the start of the diet ${ }^{(30)}$. In the study of Klement (2016), five patients with an early cancer were alive at 4 months follow up and one patient with metastatic cancer died 11 months from diagnosis ${ }^{(37)}$. Only one study compared reported and expected survival (36) indicating survival of 13 months versus expected 7.8 months in one patients and 17 months compared to expected 7.4 months in another.

Adherence

From 102 patients who started a KD intervention, 50 (49\%) were able to complete the diet. Ketosis

All studies reported ketosis; however not all patients were able to maintain ketosis. Ketosis was relatively low and ranged between 0.03 to $15 \mathrm{mmol} / \mathrm{L}$ (Table 2). Only Tan-Shalaby (2016) investigated whether patients achieved the glucose ketone index ${ }^{(30)}$ that has been proposed to monitor the efficacy of metabolic therapy ${ }^{(39)}$, however, patients did not achieved values predicted for therapeutic effects $(<1.0)$ (Supplementary Document D).

Adverse events

In total, adverse events were reported in 50 patients. Eight studies measured adverse events $^{(29 ; 30 ; 31 ; 32 ; 33 ; 35 ; 37 ; 38)}$ and four used a validated tool $(29 ; 33 ; 35 ; 37)$. Most studies reported fatigue, constipation, diarrhoea, hyperuricemia and vomiting. From 50 patients, 
22016 reported fatigue, 12 constipation, 8 diarrhoea, 8 hyperuricemia and 4 vomiting. One

221 study reported hunger in 2 and craving for sugar in 5 out of 12 patients ${ }^{(31)}$. Hyperkalaemia

222 and hypokalaemia were reported in 2 patients. Also, 2 patients experienced

223 leukocytopenia. Adverse events such as oesophagitis, anaemia, hypomagnesemia, pedal

224 oedema, halitosis, hypoglycaemia, hyperlipidaemia and deep vein thrombosis were

225 observed only once across studies.

226 Quality of life

227 Three studies assessed the QoL with validated European Organization for Research and

228 Treatment core quality of life questionnaire ${ }^{(30 ; 32 ; 37)}$. No consistent results were reported.

229

\section{Discussion}

231 From hypothetical conjecture based on academic modelling supported by animal and

232 cellular studies, KD have a sound theoretical bases for suppressing tumour growth ${ }^{(11 ; 20 \text {; }}$

$233{ }^{21)}$. However, strong conclusive evidence in clinical practice is still lacking.

234 Current studies demonstrated that patients on KD lose weight. This is of concern for 235 sarcopenic and malnourished patients as body composition and nutritional status have 236 been shown to influence clinical outcomes ${ }^{(25 ; 40)}$. However, most of the studies did not 237 monitor energy intake, and it is very likely patients followed a hypocaloric diet. This was 238 demonstrated in two studies ${ }^{(32 ; 37)}$ and possibly attributed to self-administrated diet and 239 limited diet monitoring. Also, it is widely accepted that body weight is a weak predictor of 240 changes in health status ${ }^{(41)}$, as patients might lose fat but not muscle mass ${ }^{(37)}$. Hence, 241 further studies of KD that control energy and macronutrient intake and measure body 242 composition are required.

243 This review found a low adherence to KD possibly due to a number of factors. The 244 proportion of macronutrients influence ketosis. Studies followed variable F:CHO+P ratio, 245 and thus the ketosis may have been affected by levels of carbohydrate and protein. It was 246 originally proposed that carbohydrate should be maintained below $20 \mathrm{~g}$ per day but no data 247 exist to define what level of carbohydrate represents a threshold for maintenance of 248 ketosis ${ }^{(20)}$. Studies in this review used a great variation of carbohydrate, reaching to $70 \mathrm{~g}$ 249 per day. Also, it has been suggested that a very high protein intake may counteract the 250 level of ketosis by providing glucogenic amino acids for production of glucose when the 
251

252

253

254

255

256

257

258

259

260

261

262

263

264

265

266

267

268

269

270

271

272

273

274

275

276

277

278

279

280

281

282

283

level of protein exceeds the normal non-starvation protein turnover ${ }^{(20)}$. Hence, the carbohydrate and protein ratio may explain a low ketosis.

Furthermore, the maintenance of ketosis and adherence to KD are very likely underpinned by limitations in the delivery of the diet and monitoring. Schwartz (2015) suggested that patients require weekly contact with a dietitian ${ }^{(38)}$. However, most of the studies tested self-administrated diet and had little control over the food selection, energy and nutritional composition. In contrast, Zahra (2017) provided tailored meals but the compliance was still poor, indicating that delivery of the diet represents only one contributor to adherence. The author concluded that patients found a 4:1 fat to carbohydrate ratio unpalatable ${ }^{(29)}$.

Possibly, palatability plays a crucial role and patients are unlikely to follow a restricted diet for a prolonged period of time. There were no obvious differences in adherence between studies with the original 4:1 KD and those using a Modified Atkins diet or similar macronutrient ratio. The evidence indicates that following the diet is difficult for patients, especially incorporating the diet into family life ${ }^{(32)}$. Schmidt (2011) suggested that patient's motivation is critical ${ }^{(32)}$ and that diet would only be a good option in highly motivated patients.

Furthermore, the adherence is closely related to adverse events. It is difficult to differentiate between events related to treatment and those specific to the diet, especially in very advanced cancer. Constipation, diarrhoea and fatigue were the most frequently reported problems. Due to low dietary fibre content, patients following a KD are likely to experience constipation. Studies that reported on dietary fibre showed a range between $7.9 \mathrm{~g}-12.5 \mathrm{~g} /$ day, while $20-30 \mathrm{~g} /$ day is recommended ${ }^{(42)}$. On the other hand, if a substantial proportion of fat in a diet, is not introduced gradually, it might lead to diarrhoea ${ }^{(43)}$. Also, a decrease in carbohydrate intake and simulation of fasting may lead to fatigue. These adverse events were more frequent in the first four weeks on a diet, indicating that time for adaptation is required ${ }^{(32)}$.

Concerns about acidosis, kidney and hepatic functional impairment have not been confirmed. Two studies reported hyperuricemia, which needs further investigation. Many adverse events were reported as single cases, indicating the importance of considering comorbidities when prescribing the diet ${ }^{(35)}$.

Mixed results were observed in blood parameters, tumour, quality of life and survival. No clear trend in changes of glucose and lipids could be concluded. Inverse correlation between glucose and ketones level was demonstrated only in two studies ${ }^{(33 ; 37)}$. Tumour 
responses were better in patients with early stage of disease ${ }^{(32 ; 37)}$ or with low-grade tumours when the ketogenic diet was used as a sole therapy ${ }^{\left({ }^{(3)}\right.}$. Patients with stable disease or partial remission were able to achieve 3-fold higher ketosis than patients with more progressive disease ${ }^{(33)}$. Some patients achieved outstanding results on tumour stability and survival while others progressed. Most of the studies included mixed cancer populations, and thus its is unclear what cancer site could benefit from the diet the most. However, positive responses where clearly observed in patients with brain tumours. The quality of life parameters slightly improved, worsened or remained unchanged. However, due to high level of bias, a small number of patients who had a high level of adherence to the diet, and no control group, conclusions are difficult to ascertain from the available data.

\section{Conclusion}

Current studies represent preliminary evidence and show that the KD is potentially feasible and does not cause life-threatening events in patients with cancer. However, adherence is low and possibly linked to a limitation in diet delivery, the lack of monitoring and follow up. A high level of heterogeneity among studies prevents the formulation of conclusions. To develop the evidence base for the use of KD in clinical practice, high quality control trials are required.

\section{Conflict of interests, source of funding and authorship}

The authors declare that they have no conflicts of interest. No funding has been received. Non-financial support has been provided by the University of Manchester.

\section{Transparency declaration}

The lead author affirms that this manuscript is an honest, accurate, and transparent account of the study being reported, that no important aspects of the study have been omitted and that any discrepancies from the study as planned (and registered with PROSPERO) have been explained. The reporting of this work is compliant with PRISMA guidelines. 


\section{References}

317 1. Hickson M, Child J, Collinson A (2017) Future Dietitian 2025: informing the development of a workforce

318 strategy for dietetics. Journal of human nutrition and dietetics : the official journal of the British Dietetic 319 Association.

320 2. Hazzard E, Walton K, McMahon AT et al. (2017) Nutrition-related hospital presentations and admissions 321 among radiotherapy outpatients: a systematic literature review. Journal of human nutrition and dietetics : 322 the official journal of the British Dietetic Association.

323 3. Godos J, Bella F, Sciacca S et al. (2017) Vegetarianism and breast, colorectal and prostate cancer risk: an 324 overview and meta-analysis of cohort studies. Journal of human nutrition and dietetics : the official journal 325 of the British Dietetic Association 30, 349-359.

326 4. van Tonder E, Herselman MG, Visser J (2009) The prevalence of dietary-related complementary and 327 alternative therapies and their perceived usefulness among cancer patients. Journal of human nutrition and 328 dietetics : the official journal of the British Dietetic Association 22, 528-535.

329 5. Allen BG, Bhatia SK, Anderson CM et al. (2014) Ketogenic diets as an adjuvant cancer therapy: History 330 and potential mechanism. Redox Biology 2, 963-970.

331 6. Toth C, Clemens Z (2017) Treatment of rectal cancer with the Paleolithic ketogenic diet: A 24-months 332 follow up American Journal of Medical Case Reports 5, 205-216.

333 7. Perez-Guisado J, Munoz-Serrano A, Alonso-Moraga A (2008) Spanish Ketogenic Mediterranean Diet: a 334 healthy cardiovascular diet for weight loss. Nutrition journal 7, 30.

335 8. Nebeling LC, Miraldi F, Shurin SB et al. (1995) Effects of a ketogenic diet on tumor metabolism and 336 nutritional status in pediatric oncology patients: two case reports. J Am Coll Nutr 14, 202-208.

337 9. Jenkins DJ, Wong JM, Kendall CW et al. (2009) The effect of a plant-based low-carbohydrate ("Eco338 Atkins") diet on body weight and blood lipid concentrations in hyperlipidemic subjects. Archives of internal 339 medicine 169, 1046-1054.

340 10. Allen BG, Bhatia SK, Anderson CM et al. (2014) Ketogenic diets as an adjuvant cancer therapy: History 341 and potential mechanism. Redox Biol 2, 963-970.

342 11. Warburg O (1956) On the origin of cancer cells. Science 123, 309-314.

343 12. Hanahan D, Weinberg RA (2011) Hallmarks of cancer: the next generation. Cell 144, 646-674.

344 13. Bettum IJ, Gorad SS, Barkovskaya A et al. (2015) Metabolic reprogramming supports the invasive 345 phenotype in malignant melanoma. Cancer letters 366, 71-83.

346 14. Pedersen PL (2007) Warburg, me and Hexokinase 2: Multiple discoveries of key molecular events 347 underlying one of cancers' most common phenotypes, the "Warburg Effect", i.e., elevated glycolysis in the 348 presence of oxygen. Journal of bioenergetics and biomembranes 39, 211-222.

349 15. Klement RJ, Kammerer U (2011) Is there a role for carbohydrate restriction in the treatment and 350 prevention of cancer? Nutrition \& metabolism 8, 75. 
351

352

353

354

355

356

357

358

359

360

361

362

363

364

365

366

367

368

369

370

371

372

373

374

375

376

377

378

379

380

381

382

383

384

385

386

16. Schwartz L, Seyfried T, Alfarouk KO et al. (2017) Out of Warburg effect: An effective cancer treatment targeting the tumor specific metabolism and dysregulated pH. Seminars in cancer biology 43, 134-138. 17. Seyfried TN, Yu G, Maroon JC et al. (2017) Press-pulse: a novel therapeutic strategy for the metabolic management of cancer. Nutrition \& metabolism 14, 19.

18. Boison D (2017) New insights into the mechanisms of the ketogenic diet. Current opinion in neurology 30, 187-192.

19. Branco AF, Ferreira A, Simoes RF et al. (2016) Ketogenic diets: from cancer to mitochondrial diseases and beyond. European journal of clinical investigation 46, 285-298.

20. Kapelner A, Vorsanger M (2015) Starvation of cancer via induced ketogenesis and severe hypoglycemia. Med Hypotheses 84, 162-168.

21. Klement RJ (2017) Beneficial effects of ketogenic diets for cancer patients: a realist review with focus on evidence and confirmation. Medical oncology 34, 132.

22. Erickson N, Boscheri A, Linke B et al. (2017) Systematic review: isocaloric ketogenic dietary regimes for cancer patients. Medical oncology 34, 72.

23. Oliveira CL, Mattingly S, Schirrmacher R et al. (2017) A Nutritional Perspective of Ketogenic Diet in Cancer: A Narrative Review. J Acad Nutr Diet.

24. Chung HY, Park YK (2017) Rationale, Feasibility and Acceptability of Ketogenic Diet for Cancer Treatment. Journal of cancer prevention 22, 127-134.

25. Ryan AM, Power DG, Daly L et al. (2016) Cancer-associated malnutrition, cachexia and sarcopenia: the skeleton in the hospital closet 40 years later. The Proceedings of the Nutrition Society 75, 199-211.

26. Gibson DJ, Burden ST, Strauss BJ et al. (2015) The role of computed tomography in evaluating body composition and the influence of reduced muscle mass on clinical outcome in abdominal malignancy: a systematic review. European journal of clinical nutrition 69, 1079-1086.

27. Liberati A, Altman DG, Tetzlaff J et al. (2009) The PRISMA statement for reporting systematic reviews and meta-analyses of studies that evaluate healthcare interventions: explanation and elaboration. Bmj $\mathbf{3 3 9}$, b2700.

28. CASP (2017) Critical Appraisal Skills Programme. (Cohort Study) Checklist. Dowloaded from http://wwwcasp-uknet/casp-tools-checklists.

29. Zahra A, Fath MA, Opat E et al. (2017) Consuming a Ketogenic Diet while Receiving Radiation and Chemotherapy for Locally Advanced Lung Cancer and Pancreatic Cancer: The University of lowa Experience of Two Phase 1 Clinical Trials. Radiation research 187, 743-754.

30. Tan-Shalaby JL, Carrick J, Edinger K et al. (2016) Modified Atkins diet in advanced malignancies - final results of a safety and feasibility trial within the Veterans Affairs Pittsburgh Healthcare System. Nutrition \& metabolism 13, 52.

31. Rieger J, Bahr O, Maurer GD et al. (2014) ERGO: a pilot study of ketogenic diet in recurrent glioblastoma. Int J Oncol 44, 1843-1852. 
387 388 389 390 391 392 393 394 395 396 397 398 399 400 401 402 403 404 405 406 407 408 409 410 411 412 413 414 415 416 417 418 419 420 421

32. Schmidt M, Pfetzer N, Schwab M et al. (2011) Effects of a ketogenic diet on the quality of life in 16 patients with advanced cancer: A pilot trial. Nutrition \& metabolism 8, 54.

33. Fine EJ, Segal-Isaacson CJ, Feinman RD et al. (2012) Targeting insulin inhibition as a metabolic therapy in advanced cancer: a pilot safety and feasibility dietary trial in 10 patients. Nutrition 28, 1028-1035.

34. Artzi M, Liberman G, Vaisman N et al. (2017) Changes in cerebral metabolism during ketogenic diet in patients with primary brain tumors: (1)H-MRS study. Journal of neuro-oncology 132, 267-275.

35. Champ CE, Palmer JD, Volek JS et al. (2014) Targeting metabolism with a ketogenic diet during the treatment of glioblastoma multiforme. Journal of neuro-oncology 117, 125-131.

36. Strowd RE, Cervenka MC, Henry BJ et al. (2015) Glycemic modulation in neuro-oncology: experience and future directions using a modified Atkins diet for high-grade brain tumors. Neuro-oncology practice 2, 127-136.

37. Klement RJ, Sweeney RA (2016) Impact of a ketogenic diet intervention during radiotherapy on body composition: I. Initial clinical experience with six prospectively studied patients. BMC research notes 9, 143. 38. Schwartz K, Chang HT, Nikolai M et al. (2015) Treatment of glioma patients with ketogenic diets: report of two cases treated with an IRB-approved energy-restricted ketogenic diet protocol and review of the literature. Cancer \& metabolism 3, 3.

39. Meidenbauer JJ, Mukherjee P, TN S (2015) The glucose ketone index calculator: a simple tool to monitor therapeutic efficacy for metabolic management of brain cancer. Nutr Metab (Lond) 12, 12.

40. Martin L, Birdsell L, Macdonald N et al. (2013) Cancer cachexia in the age of obesity: skeletal muscle depletion is a powerful prognostic factor, independent of body mass index. Journal of clinical oncology : official journal of the American Society of Clinical Oncology 31, 1539-1547.

41. Prado CM, Heymsfield SB (2014) Lean tissue imaging: a new era for nutritional assessment and intervention. JPEN Journal of parenteral and enteral nutrition 38, 940-953.

42. SCAN ( 2015) Carbohydrate and health. Downloaded from: https://wwwgovuk/government/uploads/system/uploads/attachment_data/file/445503/SACN_Carbohydra tes_and_Healthpdf

43. Campos H, D'Agostino M, Ordovas JM (2001) Gene-diet interactions and plasma lipoproteins: role of apolipoprotein E and habitual saturated fat intake. Genetic epidemiology 20, 117-128.

44. Abdelbary M, Elsakka A, Salah H et al. (2017) Does Metabolic management of gliomas using restricted Ketogenic diet combined with hyperbaric oxygen therapy (HBOT) improve clinical outcome and reduce epileptic risk? . Tampa: Metabolic Therapeutics Conference.

45. Anderson CM, Loth E, Opat E et al. (2016) A Phase 1 Trial of Ketogenic Diet With Concurrent Chemoradiation (CRT) in Head and Neck Squamous Cell Carcinoma (HNSCC). IJROBP 94, 898.

46. Bozzetti F, Cozzaglio L, Gavazzi C et al. (1996) Total nutritional manipulation in humans: report of a cancer patient. Clin Nutr 15, 207-209. 
47. Bozzetti F, Gavazzi C, Mariani L et al. (2004) Glucose-based total parenteral nutrition does not stimulate glucose uptake by humans tumours. Clin Nutr 23, 417-421.

48. Branca JJ, Pacini S, Ruggiero M (2015) Effects of Pre-surgical Vitamin D Supplementation and Ketogenic Diet in a Patient with Recurrent Breast Cancer. Anticancer Res 35, 5525-5532.

49. Breitkreutz R, Tesdal K, Jentschura D et al. (2005) Effects of a high-fat diet on body composition in cancer patients receiving chemotherapy: a randomized controlled study. Wiener klinische Wochenschrift 117, 685-692.

50. Brünings W (1942) Beiträge zum Krebsproblem. 2. Mitteilung: Klinische Anwendungen der diätetischhormonalen Krebsbeeinflussung ("Entzuckerungsmethode"). . Munchener Medizinische Wochenschrift 89, 71-76.

51. Brünings W (1941) Beiträge zum Krebsproblem. 1. Mitteilung: Ueber eine diätetisch-hormonale Beeinflussung des Krebses. Münch Med Wschr 88, 117-123.

52. Chaiyasit K, Tripipitsiriwat K, Srikaew K et al. (2017) Alternative Ketogenic Diet with Coconut Milk in a Case with Underlying Colorectal Cancer. Indian journal of medical and paediatric oncology : official journal of Indian Society of Medical \& Paediatric Oncology 38, 247-248.

53. Chu-Shore CJ, Thiele EA (2010) Tumor growth in patients with tuberous sclerosis complex on the ketogenic diet. Brain \& development 32, 318-322.

54. Cohen C L-JA, Gower B, Alvarez R, Leath, C, Turner T, Burton A, Goss A. (2016) A ketogenic diet improves metabolic health and decreases angiogenesis in women with recurrent ovarian cancer Ovarian cancer 26.

55. Fearon KC, Borland W, Preston T et al. (1988) Cancer cachexia: influence of systemic ketosis on substrate levels and nitrogen metabolism. The American journal of clinical nutrition 47, 42-48.

56. Jansen N, Walach H (2016) The development of tumours under a ketogenic diet in association with the novel tumour marker TKTL1: A case series in general practice. Oncol Lett 11, 584-592.

57. Moore K (2012) Using the restricted ketogenic diet for brain cancer management: comments from neuro-oncologist. In: Seyfried TN, editor. Cancer as a metabolic disease: on the origin, management, and prevention of cancer.

58. Renda L, Honea N, Dardis C et al. (2015) Abstract CT213: Clinical effects of a ketogenic diet on brain tumor patients: tumor growth and quality of life. Proceedings: AACR 106th Annual Meeting 2015; April 1822, 2015; Philadelphia, PA.

59. Santos JG, Cruz WMSD, Schonthal AH et al. (2017) Patient with Recurrent Glioblastoma Responding Favorably to Ketogenic Diet Combined with Intranasal Delivery of Perillyl Alcohol: A Case Report and Literature Review. Brazilian Neurosurgery 36, 194-199.

60. Shinojima N, Matsuzaki H, Takeshima Y et al. (2017) P18.11 The effect of ketogenic diet on survival and quality of life in patients with malignant brain tumors in palliative care. Neuro-Oncology 19, iii123. 
457 61. Schmidt M, Fetzer N, Strauss I et al. (2008) A ketogenic diet improves quality of life in some patients 458 with advanced metastatic tumours Anticancer Research 28, 4035.

459 62. Schroeder U, Himpe B, Pries R et al. (2013) Decline of lactate in tumor tissue after ketogenic diet: in vivo 460 microdialysis study in patients with head and neck cancer. Nutr Cancer 65, 843-849.

461 63. Schwalb M, Taubmann M, Hines S et al. (2016) Clinical Observation of a Novel, Complementary,

462 Immunotherapeutic Approach based on Ketogenic Diet, Chondroitin Sulfate, Vitamin D3, Oleic Acid and a

463 Fermented Milk and Colostrum Product. American Journal of Immunology 12, 91-98.

464 64. Schulte G, Schütz H (1942) Insulin in der Krebsbehandlung. Münch Med Wschr 89, 648-650.

465 65. Zuccoli G, Marcello N, Pisanello A et al. (2010) Metabolic management of glioblastoma multiforme using 466 standard therapy together with a restricted ketogenic diet: Case Report. Nutrition \& metabolism 7, 33.

467 66. Rossi-Fanelli F, Franch F, Mulieri M et al. (1991) Effect of energy substrate manipulation on tumour cell 468 proliferation in parenterally fed cancer patients. Clinical Nutrition 10, 228-232.

469

470 References for Supplementary Document $C^{(8 ; 44 ; 45 ; 46 ; 47 ; 48 ; 49 ; 50 ; 51 ; 52 ; 53 ; 54 ; 55 ; 56 ; 57 ; 58 ; 59 ; 60 ;}$ $471 \quad 61 ; 62 ; 63 ; 64 ; 65 ; 66)$ 
Figure 1 Preferred Reporting Items for Systematic Reviews and Meta-Analyses Diagram
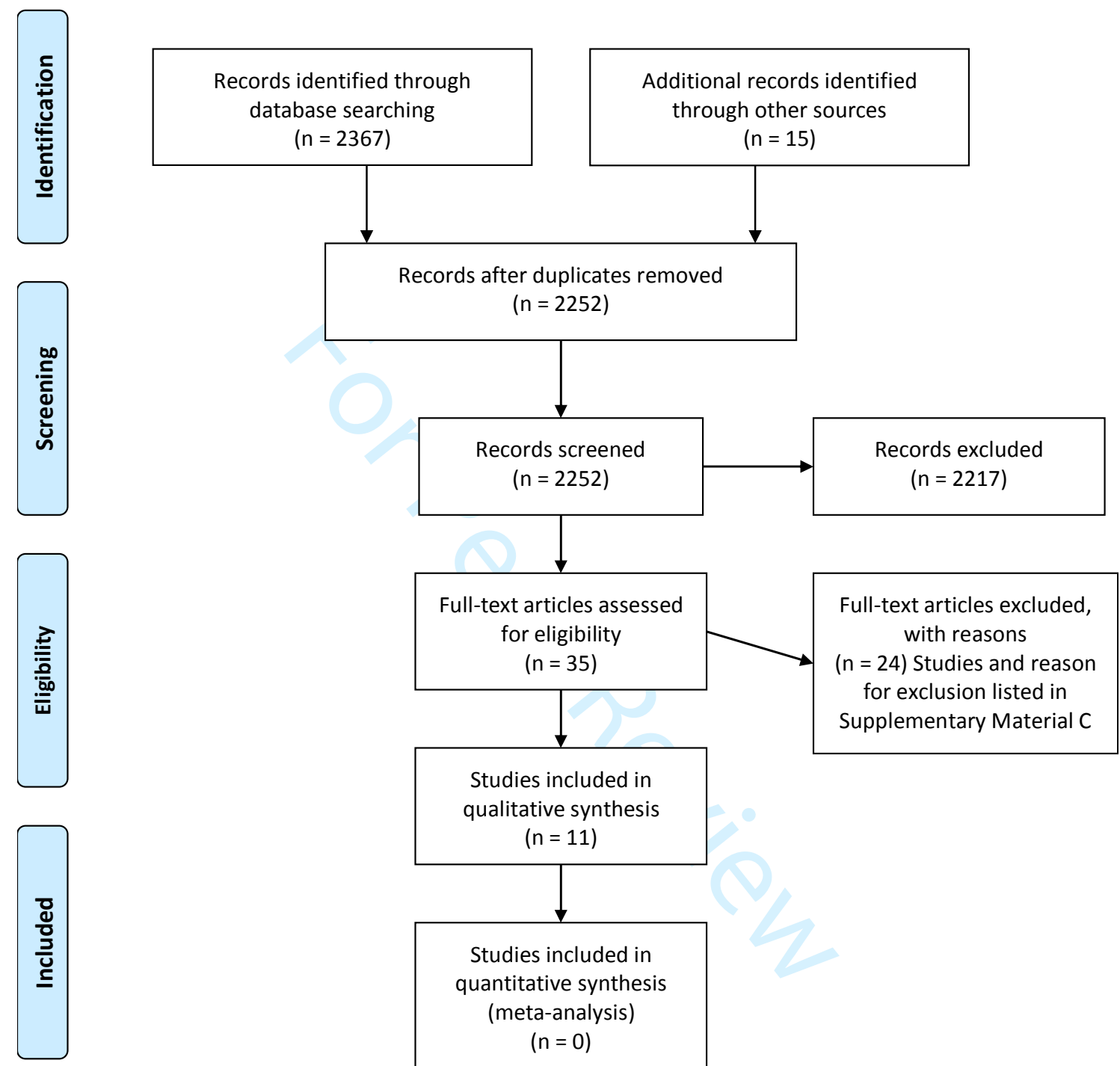

Studies included in qualitative synthesis $(n=11)$

Studies included in quantitative synthesis (meta-analysis) $(n=0)$ 
Table 1 Studies characteristics

\begin{tabular}{|c|c|c|c|c|c|c|c|c|c|}
\hline $\begin{array}{l}\text { Author/ } \\
\text { Year }\end{array}$ & Design & Sample & $\begin{array}{l}\text { Median } \\
\text { Age }\end{array}$ & $\begin{array}{l}\text { Cancer } \\
\text { Site }(n)\end{array}$ & $\begin{array}{l}\text { Cancer } \\
\text { Stage }\end{array}$ & $\begin{array}{l}\text { Treatment } \\
\text { Received }(n)\end{array}$ & Intervention & $\begin{array}{l}\text { Duration } \\
\text { weeks }\end{array}$ & Outcomes \\
\hline $\begin{array}{l}\text { Zahra } \\
2017\end{array}$ & $\begin{array}{l}\text { Single arm pilot } \\
\text { trial }\end{array}$ & 9 & $60(55-83)$ & $\begin{array}{l}\text { Lung (7) } \\
\text { Pancreatic (2) }\end{array}$ & 2 to 4 & $\begin{array}{l}\text { Chemotherapy, } \\
\text { radiation }\end{array}$ & $\mathrm{T}, \mathrm{KD}$ & $5.5-7$ & $\begin{array}{l}\text { AE, ketone, glucose levels, } \\
\text { oxidative stress, PFS }\end{array}$ \\
\hline $\begin{array}{l}\text { Rieger } \\
2014\end{array}$ & $\begin{array}{l}\text { Single arm pilot } \\
\text { trial }\end{array}$ & 20 & $57(32-72)$ & $\begin{array}{l}\text { Recurrent } \\
\text { glioblastoma }\end{array}$ & Advanced & $\begin{array}{l}\text { Radiotherapy, } \\
\text { chemotherapy }\end{array}$ & SA, KD & $6-16$ & $\begin{array}{l}\text { Adherence, PFS, survival, QoL } \\
\text { seizures frequency, ketosis, }\end{array}$ \\
\hline $\begin{array}{l}\text { Tan- } \\
\text { Shalaby } \\
2016\end{array}$ & $\begin{array}{l}\text { Single arm } \\
\text { feasibility trial }\end{array}$ & 17 & $64(42-87)$ & Mixed & Advanced & $\begin{array}{l}\text { No therapy (4)/ } \\
\text { chemotherapy }\end{array}$ & $\begin{array}{l}\text { SA, Modified } \\
\text { Atkins diet }\end{array}$ & $4-16$ & $\begin{array}{l}\text { Safety, tolerability adverse events, } \\
\text { BC, blood pressure, BP }\end{array}$ \\
\hline $\begin{array}{l}\text { Fine } \\
2012\end{array}$ & $\begin{array}{l}\text { Single arm } \\
\text { feasibility trail }\end{array}$ & 12 & $\begin{array}{l}\text { Mean/SEM } \\
62.9 \pm 2.5\end{array}$ & Mixed & Advanced & Chemotherapy PI & $S A, K D$ & 4 & Adherence, AE, metabolic effects \\
\hline $\begin{array}{l}\text { Artzi } \\
2017\end{array}$ & $\begin{array}{l}\text { Prospective } \\
\text { cohort study }\end{array}$ & $\begin{array}{l}9 \\
(5 \mathrm{KD})\end{array}$ & $\begin{array}{l}42(37-69) / \\
46(27-64)\end{array}$ & Mixed & Advanced & $\begin{array}{l}\text { No therapy/ } \\
\text { chemotherapy }\end{array}$ & $\mathrm{T}, \mathrm{KD}$ & $\begin{array}{l}2-31 \\
\text { months }\end{array}$ & $\begin{array}{l}\text { brain metabolites, tolerability, } \\
\text { tumour effect }\end{array}$ \\
\hline $\begin{array}{l}\text { Schmidt } \\
2011\end{array}$ & $\begin{array}{l}\text { Prospective } \\
\text { single arm pilot } \\
\text { study }\end{array}$ & 16 & $\begin{array}{l}50.5(30- \\
65)\end{array}$ & Mixed & Advanced & $\begin{array}{l}\text { Chemotherapy/ } \\
\text { radiation/ } \\
\text { immunotherapy }\end{array}$ & $\mathrm{SA}, \mathrm{KD}$ & 12 & QoL, BC, BP, tumour effect \\
\hline $\begin{array}{l}\text { Champ } \\
2014\end{array}$ & $\begin{array}{l}\text { Retrospective } \\
\text { study }\end{array}$ & $\begin{array}{l}53 \\
(6 \mathrm{KD})\end{array}$ & $\begin{array}{l}59.5(34- \\
62)\end{array}$ & $\begin{array}{l}\text { Glioblastoma } \\
\text { multiforme }\end{array}$ & $\begin{array}{l}\text { Stage } 3 \text { to } \\
4\end{array}$ & $\begin{array}{l}\text { Chemotherapy/ } \\
\text { chemo-radiation }\end{array}$ & $\mathrm{SA}, \mathrm{KD}$ & $\begin{array}{l}3-12 \\
\text { months }\end{array}$ & $\begin{array}{l}\text { Safety, toxicity, survival, glucose } \\
\text { level }\end{array}$ \\
\hline $\begin{array}{l}\text { Strowd } \\
2015\end{array}$ & Case reports & 8 & $\begin{array}{l}\text { Mean/SD } \\
41.5 \pm 10\end{array}$ & Mixed & Advanced & $\begin{array}{l}\text { No therapy/ } \\
\text { chemotherapy }\end{array}$ & $\begin{array}{l}\text { SA, Modified } \\
\text { Atkins diet }\end{array}$ & $\begin{array}{l}2-24 \\
\text { months }\end{array}$ & Adherence, $B C$, tumour effect \\
\hline $\begin{array}{l}\text { Klement } \\
2016\end{array}$ & Case reports & 6 & $62(40-74)$ & Mixed & $\begin{array}{l}\text { Stage } 1 \text { to } \\
4\end{array}$ & $\begin{array}{l}\text { Radiation/radio- } \\
\text { chemotherapy }\end{array}$ & $S A, K D$ & $\begin{array}{l}32-73+ \\
\text { days }\end{array}$ & QoL, BC, BP \\
\hline $\begin{array}{l}\text { Schwartz } \\
2015\end{array}$ & Case reports & 2 & 55 and 52 & $\begin{array}{l}\text { Glioblastoma } \\
\text { multiforme }\end{array}$ & Advanced & $\begin{array}{l}\text { Surgery/radiation/ } \\
\text { chemotherapy PI }\end{array}$ & SA, KD & 12 & Adherence, BP, tumour effect \\
\hline $\begin{array}{l}\text { Toth } \\
2016\end{array}$ & Case report & 1 & 62 & Rectal & $\begin{array}{l}\text { Early } \\
\text { stage }\end{array}$ & Radiation PI & $\mathrm{SA}, \mathrm{KD}$ & $\begin{array}{l}22.5 \\
\text { months }\end{array}$ & $\begin{array}{l}\text { Adherence, AE, IP, organs } \\
\text { function, } \mathrm{BP} \text {, tumour effect }\end{array}$ \\
\hline
\end{tabular}


AE - adverse events, BC- body composition, BP- biochemical parameters, IP- intestinal permeability, Interv -intervention, KD- ketogenic diet, SA- self administrated, PFSprogression free survival, QoL- quality of life, PI- prior intervention, SD- standard deviation, SEM- standard error of the mean, T-tailored, vs- versus

Table 2 Outcomes reported in the included studies

\begin{tabular}{|c|c|c|c|c|c|c|c|}
\hline Study & $\begin{array}{l}\text { Mean body } \\
\text { weight change }\end{array}$ & $\begin{array}{l}\text { Body } \\
\text { composition }\end{array}$ & $\begin{array}{l}\text { Blood } \\
\text { glucose }\end{array}$ & Lipid profile & Other blood measures & Tumour effects & Adherence \\
\hline $\begin{array}{l}\text { Zahra } \\
2017\end{array}$ & $\begin{array}{l}\text { lung pts }-5.6 \mathrm{~kg} \\
\text { pancreatic pts }-8.15 \mathrm{~kg}\end{array}$ & $N R$ & NSD & NR & $\begin{array}{l}\uparrow \text { protein carbonyl vs } \\
\text { baseline }\end{array}$ & 2 stable, 7 progressed & $3 / 9$ \\
\hline $\begin{array}{l}\text { Rieger } \\
2014\end{array}$ & $-1.86 \mathrm{~kg}$ & NR & NSD & $\begin{array}{l}\text { NSD in TG, } \\
\text { cholesterol, HDL, } \\
\text { LDL }\end{array}$ & NSD in $\mathrm{HbA} 1 \mathrm{c}$ values & $\begin{array}{l}1 \text { complete, } 5 \text { partial } \\
\text { responses, } 1 \mathrm{NR}\end{array}$ & $8 / 20$ \\
\hline $\begin{array}{l}\text { Tan- } \\
\text { Shalaby } \\
2016\end{array}$ & $-12.3 \pm 6.0 \mathrm{~kg}$ & NR & NSD & $\begin{array}{l}\text { NSD in } \\
\text { cholesterol LDL, } \\
\text { HDL, TG }\end{array}$ & $\begin{array}{l}\text { NSD in urea } \\
\text { nitrogen/creatinine } \\
\text { ratio, creatinine, } \\
\text { albumin and uric acid }\end{array}$ & $\begin{array}{l}3 \text { stable, } 1 \text { reduced } \\
\text { symptoms }\end{array}$ & $4 / 17$ \\
\hline $\begin{array}{l}\text { Fine } \\
2012\end{array}$ & $-3 \mathrm{~kg}$ SME 0.5 & NR & $\begin{array}{l}\text { mean/SEM } \downarrow 3.2 \\
( \pm 3.7) \mathrm{mg} / \mathrm{dl} \text { vs } \\
\text { baseline }\end{array}$ & NR & $\begin{array}{l}\downarrow \text { in insulin by } 75 \% \text { to } \\
90 \% \text { vs baseline }\end{array}$ & $\begin{array}{l}5 \text { stable, } 1 \text { partial } \\
\text { remission, } 4 \text { progressed }\end{array}$ & $5 / 12$ \\
\hline $\begin{array}{l}\text { Artzi } \\
2017\end{array}$ & NR & NR & NR & NR & $\begin{array}{l}\text { NSD in brain } \\
\text { metabolism }\end{array}$ & 1 stable, 4 progressed & $4 / 5$ \\
\hline $\begin{array}{l}\text { Schmidt } \\
2011\end{array}$ & $-2 \mathrm{~kg}$ & NR & $\begin{array}{l}\text { with exception of } 1 \text { pt } \\
\text { all } \downarrow\end{array}$ & $\begin{array}{l}\downarrow \text { in pts with } \\
\text { elevated TG, } \\
\text { cholesterol, sig } \downarrow \\
\text { mean LDL, HDL }\end{array}$ & $\begin{array}{l}\text { sig improved liver } \\
\text { parameters, } 1 \mathrm{pt} \text { with } \\
\text { diabetes } \downarrow 75 \% \text { of initial } \\
\text { insulin units }\end{array}$ & 5 progressed, 5 stable & $5 / 16$ \\
\hline $\begin{array}{l}\text { Champ } \\
2014\end{array}$ & $-7.9 \mathrm{~kg}$ & NR & $\begin{array}{l}\downarrow \text { from mean } 142.5 \\
(82-181) \mathrm{mg} / \mathrm{dl} \text { to } 84 \\
(76-93) \mathrm{mg} / \mathrm{dl}\end{array}$ & NR & NR & $\begin{array}{l}5 \text { progressed, } 1 \text { without } \\
\text { recurrence for } 12 \text { months }\end{array}$ & $6 / 6$ \\
\hline
\end{tabular}




\begin{tabular}{|c|c|c|c|c|c|c|c|}
\hline $\begin{array}{l}\text { Strowd } \\
2015\end{array}$ & $-3.4 \pm 6.5 \mathrm{~kg}$ & NR & NSD & $\begin{array}{l}\text { NSD in } \\
\text { cholesterol, LDL, } \\
\text { HDL, TG }\end{array}$ & NSD in creatinine & $\begin{array}{l}5(63 \%) \text { at least } 50 \% \\
\text { reduction in seizure } \\
\text { frequency, } 4 \text { seizures free }\end{array}$ & $7 / 8$ \\
\hline $\begin{array}{l}\text { Klement } \\
2016\end{array}$ & $\downarrow N R$ & $\begin{array}{l}\text { sig FM } \downarrow \text { FFM } \uparrow \\
\text { relative to body } \\
\text { weight }\end{array}$ & NSD & $\begin{array}{l}\text { NSD in LDL, HDL, } \\
\text { cholesterol, TG }\end{array}$ & $\begin{array}{l}\text { NSD in CRP, IGF-1, } \\
\text { TSH, creatinine, } \\
\text { HbA1c, insulin, ALT, } \\
\text { AST }\end{array}$ & $\begin{array}{l}5 \text { tumour regressions, } 1 \\
\text { progressed }\end{array}$ & $6 / 6$ \\
\hline $\begin{array}{l}\text { Schwartz } \\
2015\end{array}$ & NR & NR & $\begin{array}{l}1 \text { after discharge } \uparrow> \\
80 \mathrm{mg} / \mathrm{dl}, 1 \text { not below } \\
80 \mathrm{mg} / \mathrm{dl}\end{array}$ & $\begin{array}{l}1 \text { cholesterol } \uparrow \text { to } \\
281 \text { at } 6 \text { weeks, } \\
\text { after } 12 \text { weeks to } \\
252, \text { LDL } \uparrow \text { to } 197 \\
\text { after } 6 \text { weeks, to } \\
182 \text { at } 12 \text { weeks }\end{array}$ & NR & progressed & $1 / 2$ \\
\hline $\begin{array}{l}\text { Toth } \\
2016\end{array}$ & $-13 \mathrm{~kg}$ & NR & decrease & $\begin{array}{l}\uparrow \text { lipid enzymes, } \\
\text { slight } \uparrow \\
\text { cholesterol, LDL, } \\
\text { TG low }\end{array}$ & $\begin{array}{l}\text { normal renal, liver, } \\
\text { thyroid, inflammatory } \\
\text { markers }\end{array}$ & $\begin{array}{l}\downarrow \text { tumour markers, stable } \\
\text { on diet, after } 24 \text { months } \\
\text { progressed }\end{array}$ & $1 / 1$ \\
\hline
\end{tabular}

ALT- alanine aminotransferase, AST- aspartate aminotransferase, BHB -beta hydroxy butyrate, CRP - C reactive protein, FM - fat mass, FFM - fat free mass, HDL- high density lipoprotein, HbA1- haemoglobin A1, IGF 1/2 - insulin-like growth factor1/2, LDL -low density lipoprotein, NR-not reported, NSD -no significant difference, pt/ptspatient/s sig- significant, TG -triglycerides, vs -versus 


\section{Supplementary Document A - Search strategy}

MEDLINE search - Ovid interference

1. ketogenic diet.mp. or Ketogenic Diet/

2. carbohydrate restricted diet.mp. or Diet, Carbohydrate-Restricted/

3. high fat diet.mp. or Diet, High-Fat/

4. cancer.mp. or Neoplasms/

5. (tumor or tumour or carcinoma or sarcoma).mp. [mp=title, abstract, original title, name of substance word, subject heading word, keyword heading word, protocol supplementary concept word, rare disease supplementary concept word, unique identifier, synonyms]

6. 1 or 2 or 3

7. 4 or 5

8. 6 and 7

9. limit 8 to humans

10. limit 9 to "all adult (18 plus years)"

\section{Authors note}

While creating the search strategy, we considered including body composition, metabolism, inflammation, chemotherapy, radiotherapy as key words, however, the search results were unnecessary reduced. With the proposed general search, we judged that there was a higher chance to reach all the relevant publications. 


\section{Supplementary Document B - Quality Assessment using the Critical Appraisal Skills Programme tools for cohort studies}

\begin{tabular}{|c|c|c|c|c|c|c|c|c|c|c|c|c|c|c|c|}
\hline $\begin{array}{l}\text { Author/ } \\
\text { Year }\end{array}$ & Design & $\begin{array}{l}\text { Clearly } \\
\text { addressed } \\
\text { issue? }\end{array}$ & $\begin{array}{l}\text { Cohort } \\
\text { recruitment } \\
\text { acceptable? }\end{array}$ & $\begin{array}{c}\text { Exposure } \\
\text { accurately } \\
\text { measured } \\
\text { to } \\
\text { minimise } \\
\text { bias? }\end{array}$ & $\begin{array}{c}\text { Outcomes } \\
\text { accurately } \\
\text { reported } \\
\text { to } \\
\text { minimise } \\
\text { bias? }\end{array}$ & $\begin{array}{c}\text { All } \\
\text { important } \\
\text { confoundin } \\
\text { g factors } \\
\text { identified? }\end{array}$ & $\begin{array}{c}\text { Confounding } \\
\text { factors } \\
\text { taken into } \\
\text { account in } \\
\text { analysis? }\end{array}$ & $\begin{array}{l}\text { Following } \\
\text { up of } \\
\text { subjects } \\
\text { complete } \\
\text { enough? }\end{array}$ & $\begin{array}{l}\text { Following } \\
\text { up of } \\
\text { subjects } \\
\text { long } \\
\text { enough? }\end{array}$ & $\begin{array}{l}\text { What are } \\
\text { the results? }\end{array}$ & $\begin{array}{l}\text { How } \\
\text { precise } \\
\text { are the } \\
\text { results? }\end{array}$ & $\begin{array}{c}\text { Are } \\
\text { results } \\
\text { reliable? }\end{array}$ & $\begin{array}{c}\text { Can results } \\
\text { be applied } \\
\text { to the local } \\
\text { population } \\
?\end{array}$ & $\begin{array}{c}\text { Fit results } \\
\text { with other } \\
\text { available } \\
\text { evidence? }\end{array}$ & $\begin{array}{c}\text { What are } \\
\text { the } \\
\text { implications } \\
\text { for } \\
\text { practice? }\end{array}$ \\
\hline $\begin{array}{l}\text { Zahra } \\
2017\end{array}$ & $\begin{array}{l}\text { Single } \\
\text { arm pilot } \\
\text { trial }\end{array}$ & Yes & No & No & Yes & Cannot tell & No & Yes & Yes & $\begin{array}{l}\text { Adherence, } \\
\text { survival }\end{array}$ & $\begin{array}{c}95 \% \mathrm{Cl} \\
\text { not given }\end{array}$ & $\begin{array}{c}\text { Cannot } \\
\text { tell }\end{array}$ & No & Yes & NIL \\
\hline $\begin{array}{l}\text { Rieger } \\
2014\end{array}$ & $\begin{array}{l}\text { Single } \\
\text { arm pilot } \\
\text { trial }\end{array}$ & Yes & No & No & No & Yes & No & Yes & Yes & $\begin{array}{l}\text { Feasibility, } \\
\text { survival }\end{array}$ & $\begin{array}{c}95 \% \mathrm{Cl} \\
\text { not given }\end{array}$ & $\begin{array}{c}\text { Cannot } \\
\text { tell }\end{array}$ & Yes & Yes & NIL \\
\hline $\begin{array}{c}\text { Tan- } \\
\text { Shalaby } \\
2016\end{array}$ & $\begin{array}{c}\text { Single } \\
\text { arm } \\
\text { feasibility } \\
\text { trial }\end{array}$ & Yes & Yes & No & No & Yes & No & Yes & Yes & $\begin{array}{c}\text { Feasibility, } \\
\text { QoL, } \\
\text { survival }\end{array}$ & $\begin{array}{c}95 \% \mathrm{Cl} \\
\text { not given }\end{array}$ & $\begin{array}{c}\text { Cannot } \\
\text { tell }\end{array}$ & No & Yes & NIL \\
\hline Fine 2012 & $\begin{array}{c}\text { Single } \\
\text { arm } \\
\text { feasibility } \\
\text { trial }\end{array}$ & Yes & No & Yes & Yes & Yes & No & Yes & Yes & $\begin{array}{c}\text { Feasibility, } \\
\text { safety, } \\
\text { tumour } \\
\text { effects }\end{array}$ & $\begin{array}{c}\text { Yes but } \\
\text { not all } \\
\text { outcome } \\
\text { s }\end{array}$ & $\begin{array}{c}\text { Cannot } \\
\text { tell }\end{array}$ & No & Yes & NIL \\
\hline Artzi 2017 & $\begin{array}{l}\text { Prospecti } \\
\text { ve cohort } \\
\text { study }\end{array}$ & Yes & No & No & No & Yes & No & Yes & Yes & $\begin{array}{c}\text { Brain } \\
\text { metabolism } \\
\text { changes }\end{array}$ & $\begin{array}{c}\mathrm{Cl} 95 \% \\
\text { not given }\end{array}$ & $\begin{array}{c}\text { Cannot } \\
\text { tell }\end{array}$ & Yes & Yes & NIL \\
\hline $\begin{array}{c}\text { Schmidt } \\
2011\end{array}$ & $\begin{array}{l}\text { Prospecti } \\
\text { ve single } \\
\text { arm pilot } \\
\text { study }\end{array}$ & Yes & Yes & No & Yes & Yes & No & Yes & Yes & $\begin{array}{l}\text { Tolerability, } \\
\text { QoL, } \\
\text { biochemical } \\
\text { markers }\end{array}$ & $\begin{array}{c}\mathrm{Cl} 95 \% \\
\text { not given }\end{array}$ & $\begin{array}{c}\text { Cannot } \\
\text { tell }\end{array}$ & No & Yes & NIL \\
\hline
\end{tabular}




\section{Supplementary Document C Excluded studies}

\begin{tabular}{|c|c|}
\hline Study/ Year & Reason for exclusion based on our study selection criteria \\
\hline Abdelbary $2017^{(44)}$ & abstract (conference published) \\
\hline Anderson $2016^{(45)}$ & abstract (conference published) \\
\hline Bozzetti $1996^{(46)}$ & parenteral nutrition \\
\hline Bozzetti $2004^{(47)}$ & parenteral nutrition \\
\hline Branca $2015^{(48)}$ & two interventions $=$ ketogenic diet and vitamin $D$ intervention \\
\hline Breitkreutz $2005^{(49)}$ & ketones not measured \\
\hline Brünings $1941^{(51)}$ & two interventions $=$ ketogenic diet and insulin intervention \\
\hline Brünings $1942^{(50)}$ & two interventions $=$ ketogenic diet and insulin intervention \\
\hline Chaiyasit $217^{(52)}$ & abstract \\
\hline Chu-Shore $2010^{(53)}$ & study with children \\
\hline Cohen $2016^{(54)}$ & abstract (conference paper) \\
\hline Fearon $1988^{(55)}$ & short intervention \\
\hline Jansen $2016^{(56)}$ & ketones not measured \\
\hline Moore $2012^{(57)}$ & overview from clinical practice \\
\hline Nebeling $1995^{(8)}$ & study with adolescent girls \\
\hline Renda $2015^{(58)}$ & abstract \\
\hline Rossi-Fanelli $1991^{(66)}$ & parenteral nutrition \\
\hline Santos $2017^{(59)}$ & two interventions $=$ ketogenic diet and perillyl alcohol intervention \\
\hline Shinojima $2017^{(60)}$ & study with children \\
\hline Schmidt $2008^{(61)}$ & abstract \\
\hline Schroeder $2013^{(62)}$ & short intervention \\
\hline Schwalb $2016^{(63)}$ & abstract \\
\hline Shulte $1942^{(64)}$ & two interventions $=$ ketogenic diet and insulin intervention \\
\hline Zuccoli $2010^{(66)}$ & two interventions $=$ ketogenic diet and fasting \\
\hline
\end{tabular}




\section{Supplementary Document D - Diet delivery}

\begin{tabular}{|c|c|c|c|c|c|c|c|c|}
\hline $\begin{array}{l}\text { Author } \\
\text { Year }\end{array}$ & Nutrition details & Delivery of diet & Ketosis monitoring & $\begin{array}{c}\text { Mean } \\
\text { baseline } \\
\text { nutritional status }\end{array}$ & $\begin{array}{c}\text { Diet } \\
\text { monitoring }\end{array}$ & $\begin{array}{l}\text { Dietitian } \\
\text { involved }\end{array}$ & $\begin{array}{l}\text { Intervention } \\
\text { duration } \\
\text { [weeks] }\end{array}$ & $\begin{array}{l}\text { Actual length on } \\
\text { diet [weeks] }\end{array}$ \\
\hline $\begin{array}{l}\text { Zahra } \\
2017\end{array}$ & $\begin{array}{l}\mathrm{F}: \mathrm{CHO}+\mathrm{P} \text { ratio } 4: 1, \mathrm{~F} \\
90 \%, \mathrm{P} 8 \%, \mathrm{CHO} 2 \%\end{array}$ & $\begin{array}{l}\text { Commercial powder } \\
\text { drink, modified meals, } \\
\text { discretionary food }\end{array}$ & $\begin{array}{l}\text { Weekly in serum, } \\
\text { daily-finger stick, } \\
(0.6-6 \mathrm{mmol} / \mathrm{l})\end{array}$ & NR & $\begin{array}{l}\text { Metabolic } \\
\text { kitchen } \\
\text { meals }\end{array}$ & Yes & 5.5 to 7 & $\begin{array}{c}\text { Mean } \\
\text { lung pts } 2.4, \\
\text { pancreatic pts } 3\end{array}$ \\
\hline $\begin{array}{l}\text { Rieger } \\
2014\end{array}$ & $\mathrm{CHO} \max 60 \mathrm{~g} /$ day & $\begin{array}{l}\text { Fermented yoghurt } \\
\text { drinks, two plant oils. }\end{array}$ & $\begin{array}{l}2-3 \text { times a week, } \\
(0.03-1 \mathrm{mmol} / \mathrm{l})\end{array}$ & $78.3 \pm 16.1 \mathrm{~kg}$ & NR & NR & $6-16$ & $\begin{array}{c}\text { Median } 5 \text { weeks } \\
\text { (range 3-16) }\end{array}$ \\
\hline $\begin{array}{c}\text { Tan- } \\
\text { Shalaby } \\
2016\end{array}$ & CHO 20-40 g/day & $\begin{array}{c}\text { Meat, fish, dairy, } \\
\text { green leafy vegetable }\end{array}$ & $\begin{array}{c}\text { Baseline, 4, 6, } 8 \\
\text { weeks. } \\
\text { (at } 4 \text { weeks mean } \\
12.08 \mathrm{mg} / \mathrm{dl} \text {, at } 8 \\
\text { weeks } 6.17 \mathrm{mg} / \mathrm{dl} \text { ) }\end{array}$ & $\begin{array}{c}92 \pm 2.3 \mathrm{~kg}, \\
29.46 \pm 5 \mathrm{~kg} / \mathrm{m}^{2}\end{array}$ & NR & NR & 16 & 4 to 16 \\
\hline $\begin{array}{l}\text { Fine } \\
2012\end{array}$ & $\begin{array}{c}\text { El } 1236 \text { kcal, CHO } 27 \\
\text { g/day, F } 81 \text { g/day, P } \\
89.5 \text { g/day }\end{array}$ & $\begin{array}{l}\text { Increased fat and } \\
\text { protein consumption }\end{array}$ & $\begin{array}{l}\text { Weekly in serum, } \\
\text { (mean/SEM } 10.9 \pm \\
1.7 \mathrm{mg} / \mathrm{dl})\end{array}$ & $\begin{array}{c}\text { Mean } / \text { SEM } \\
73 \pm 0.9 \mathrm{~kg} \\
27.2 \pm 1.2 \mathrm{~kg} / \mathrm{m}^{2}\end{array}$ & $\begin{array}{l}\text { Dietary } \\
\text { recall }\end{array}$ & NR & 4 & $\begin{array}{c}26 \text { to } 28 \\
\text { days }\end{array}$ \\
\hline $\begin{array}{l}\text { Artzi } \\
2017\end{array}$ & $\mathrm{~F}: \mathrm{CHO}+\mathrm{P}$ ratio $4: 1$ & $\begin{array}{c}\text { Commercial drink and } \\
\text { soya bean diet }\end{array}$ & $\begin{array}{c}\text { Daily in urine, } \\
\text { (score } 2+\text { to } 4+, \\
\text { high) }\end{array}$ & NR & NR & Yes & NS & $\begin{array}{l}2 \text { to } 31 \\
\text { months }\end{array}$ \\
\hline $\begin{array}{c}\text { Schmidt } \\
2011\end{array}$ & $\mathrm{CHO}<70$ g/day & $\begin{array}{l}\text { Two oil-protein } \\
\text { shakes, } 1 \text { tablespoon } \\
\text { of the oil with } 3 \text { main } \\
\text { meals }\end{array}$ & $\begin{array}{l}\text { Daily in urine, } \\
\text { (1 to } 8 \mathrm{mmol} / \mathrm{l})\end{array}$ & $\begin{array}{c}68.5 \pm 6.8 \mathrm{~kg} \\
23.5 \pm 6.0 \mathrm{~kg} / \mathrm{m}^{2}\end{array}$ & $\begin{array}{l}\text { In person, } \\
\text { phone } \\
\text { calls }\end{array}$ & NR & 12 & 12 \\
\hline
\end{tabular}




\begin{tabular}{|c|c|c|c|c|c|c|c|c|}
\hline $\begin{array}{c}\text { Champ } \\
2014\end{array}$ & $\begin{array}{c}\text { CHO } 30-50 \text { g/day } 8 \%, \\
\text { F } 77 \% \text {, P } 15 \%\end{array}$ & $\begin{array}{c}\text { Vegetable, meat, } \\
\text { fish, egg, cream, nuts } \\
\text { and oils }\end{array}$ & $\begin{array}{c}\text { Biweekly in serum, } \\
\text { daily in urine } \\
\text { (NR/5.6/14.1 } \\
\mathrm{mg} / \mathrm{dl})\end{array}$ & $85.7 \mathrm{~kg}$ & $\begin{array}{c}\text { Diet } \\
\text { software }\end{array}$ & NR & NS & $\begin{array}{l}3 \text { to } 12 \\
\text { months }\end{array}$ \\
\hline $\begin{array}{l}\text { Strowd } \\
2015\end{array}$ & CHO 20g/day & $\begin{array}{l}\text { High-fat foods. } \\
\text { multivitamin, vitamin } \\
\text { D, calcium }\end{array}$ & $\begin{array}{c}\text { Biweekly then } \\
\text { weekly, NR }\end{array}$ & $\begin{array}{c}78.8 \pm 18.3 \mathrm{~kg} \\
25.7 \pm 3.5 \mathrm{~kg} / \mathrm{m}^{2}\end{array}$ & NR & NR & NR & $\begin{array}{c}\text { Median } \\
13.2 \text { months } \\
\text { (range 2-24) }\end{array}$ \\
\hline $\begin{array}{c}\text { Klement } \\
2016\end{array}$ & $\begin{array}{c}\mathrm{F}: \mathrm{CHO}+\mathrm{P} \text { ratio } 0.8: 1 \\
\text { to1.8:1, mean } \mathrm{El} \\
2043.5 \mathrm{kcal}, \mathrm{CHO} \\
32.3 \mathrm{~g} / \text { day, } \mathrm{P} \\
100.2 \mathrm{~g} / \text { day, } \mathrm{F} 166.7 \mathrm{~g} / \\
\text { day }\end{array}$ & $\begin{array}{l}\text { Olive, coconut oil, } \\
\text { butter, ghee, fatty } \\
\text { fish, cheese, meat } \\
\text { and non-starchy } \\
\text { vegetables }\end{array}$ & $\begin{array}{c}\text { Daily in urine, } 3 \mathrm{x} \text { in } \\
\text { blood, }(0.03 \text { to } 1.31 \\
\mathrm{mmol} / \mathrm{l})\end{array}$ & $82.02 \mathrm{~kg}$ & $\begin{array}{l}\text { Food } \\
\text { diaries }\end{array}$ & Yes & NS & $\begin{array}{c}32 \text { to } 73+ \\
\text { days }\end{array}$ \\
\hline $\begin{array}{c}\text { Schwartz } \\
2015\end{array}$ & $\begin{array}{l}\mathrm{F}: \mathrm{CHO}+\mathrm{P} \text { ratio } 3: 1, \mathrm{P} \\
0.6 \mathrm{~g} / \mathrm{kg} \text { body weight }\end{array}$ & Commercial drink & $\begin{array}{l}\text { Daily in blood, } \\
\text { (score } 2 \text { to } 4 \text { ) }\end{array}$ & $\begin{array}{c}27 \mathrm{~kg} / \mathrm{m}^{2} \\
24.3 \mathrm{~kg} / \mathrm{m}^{2}\end{array}$ & $\begin{array}{l}\text { Phone } \\
\text { calls }\end{array}$ & Yes & 12 & 4 to 12 \\
\hline $\begin{array}{l}\text { Toth } \\
2016\end{array}$ & F- $P$ ratio $2: 1$ & $\begin{array}{l}\text { Meat and fat, root } \\
\text { vegetables }<30 \%\end{array}$ & $\begin{array}{l}\text { Daily in urine, } \\
\text { (score } 1+\text { to } 3+\text { ) }\end{array}$ & $\begin{array}{c}78 \mathrm{~kg} \\
25.5 \mathrm{~kg} / \mathrm{m}^{2}\end{array}$ & $\begin{array}{l}\text { Personal } \\
\text { visits, } \\
\text { phone } \\
\text { calls, } \\
\text { emails }\end{array}$ & NR & NS & $\begin{array}{c}22.5 \\
\text { months }\end{array}$ \\
\hline
\end{tabular}

CHO- carbohydrate, F- fat, NR- not reported, NS - not stated, P-protein, pt/pts- patient/s 